


\section{A D D RES S}

DELIVERED BEFORE THE

\section{NEW-YORK STATE AGRIOULTURAL SOOIETY,}

\section{AT THE CAPITOI,}

IN THE CITY OF ALBANY,

On the Evening of the 18th January, 1849,

\section{B Y LEW IS F、A L LEN, \\ Late President of the Society.}

PUBLISHED BY ORDER OF THE ASSEMBLY.

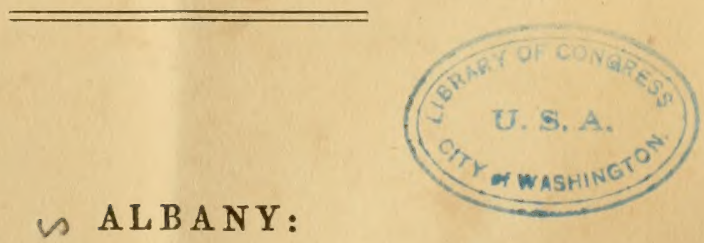

WEED, PARSONS \& CO., PUBLIC PRINTERS

1849. 
$55^{23}$ 
STATE OF NEW-YORK, ?

IN ASSEmbiy, January 19, 1849.

Resolved, That the late President of the State Agricultural Society be requested to furnish to this House for publication, a copy of his able agricultural address, delivered in the Assembly chamber before the Society, on the evening of the 18th in. stant.

\section{NEW-YORK STATE AGRICULTURAL SOCIETY, AgRICULTURAL Rooms, Albany, January, 19 th, 1849.}

HoN. A. K. HADLEY, Speaker of the Assembly:

DEAR SIR :-Lewis F. Allen, Esq., late President, "having presented to the Executive Committee a resolution of your honorable body for " a copy of his able address, delivered on the evening of the 18 th instant, before the Society for publication." I am instructed by the Executive Committee to return to the Hon. the Assembly their most sincere thanks for this testimonial of approbation to the cause of Agriculture, and to the Society whose interests they are endeavoring to promote, as well as to the late respected President of our Society; and that they most cheerfully comply with the request presented. I send herewith a copy of the address, which had been delivered over to our Society by the President, Mr. Allen, previous to his recention of the resolution of your honorable body.

I have the honor to be,

Most respectfully,

Your obt. servt.,

B. P. JOHNSON,

Cor. Secretary N. Y. S. Ag. Society.

In Assembuy, January 22d, 1849.

Kssolvcd, That twenty times the usual number of copies of the said address be IXiite. Ifo: the use of the Legislature, and five hundred copies for the Agricultural s.วะiวt:".

By order.

PHILANDER B. PRINDLE, Clerk of the Assembly, 



\section{A D D R E S .}

Gentlemen of the New-York State Agricultural Society.The year has closed upon you with a season of prosperity to your general interests ; of abundance in the productions of your husbandry ; and, I trust, of usual health to your families. Grateful to the Giver of all good for the manifold blessings showered upon us, it becomes us to improve the signal advantages we enjoy, and commence the new year of our action with invigorated efforts in the great labor with which we are charged.

The magnitude of the operations of this Society, constituted of those representing the most numerous body of our population; relying solely upon the popular approbation for its support and its success; built up during a series of years, by the strong efforts and ready hands of its managers and contributors ; fostered by the bounty of the public; and cheered by the approbation and the recognition of the Legislature, its position has become one of marked responsibility, extensive usefulness, and of State, nay, of national importance.

In the annual address which custom has sanctioned, and seemed to make imperative on your presiding officer, it can hardly be expected that, aside from a general view of the progress and affairs of your Society, both of which are more correctly detailed in the reports with which you have been favored than could be here given, a learned or 
professional discourse should be the burthen of his valedictory. Such certainly cannot be that of mine; and I shall intrude no further on the important proceedings before you, than to give such passing notice as the subject may demand, to the practical objects connected with your institution.

A period of seven years, since the present organization of our Society, has passed, and it may be not without interest, and instruction to review the history of the efforts which have been made to attain our present position, and to advert slightly to the progress we have accomplished, as the result of well directed and systematic action to promote organization and improvement in the most neglected, yet most important of all the arts of civilized life.

Passing unnoticed the occasional efforts of eminent individuals in the last century to excite public attention to agricultural improvement, the late transactions of the "Board of Agriculture" of this State are the most prominent, previous to the action of the present Society. In the month of April, 1819, the Legislature passed a law distributing $\$ 10,000$ per annum to the several counties for the term of two years, for the improvement of agriculture, and confided the trust to a Board of Managers; and in March, 1820, the Legislature extended the act to a further term of four years. The results of this beneficent measure were immediately felt throughout the entire State, most of the counties forming agricultural societies, and many individuals making spirited exertions in the improvement of their farms, crops, domestic animals, and household manufactures. Under the awakened influence of this law, an agricultural paper was commenced in the city of Albany, patronized and recommended by the Board of Agriculture, and a considerable circulation in this and the neighboring States obtained. A biennial volume of "Memoirs of the Board of Agriculture," amounting to three in number, was published 
by the managers, containing much useful matter; but from the absence of that practical management only to be ohtained through an experience in the daily routine of agricultural affairs, and a failure to enlist the affections of the farmers generally in the operations and proceedings of the local societies, the necessary interest flagged in their support, and after a few exhibitions, most of them expired a natural death, while but few survived their legal probation. The State patronage expired by its own limitation; the volumes of "Memoirs" lay uncalled for in the offices of the different county clerks, and the Albany "Plough Boy" engulphed in politics, died out by its own inanition.

Thus passed the agricultural action of 1819 through to 1825 . And although many wise, benevolent, and active men were engaged in promoting the immediate welfare of the agricultural community by efforts to excite their own self-improvement, the farming interest was not sufficiently alive to profit as it ought by either the State bounty, or those individual efforts. The law had become odious and unpopular; mainly because the recipients of that bounty knew not how to use it; and agriculture sunk again to the dull monotony of its former labors, and was left to individual improvement as occasion, accident, or private enterprise should determine. Still, this measure effected great good. Numerous instances of decided progress became manifest under the stimulus of competition at the different county cattle shows; and men of wealth, attached to agricultural interests, and of other professions became active promoters of improvement in various departments of husbandry. It was under the stimulating influences of that law that your late distinguished fellow citizens $R_{U-}$ fus King imported the Devon, and Stephen Van Rensselaer, the Short Horn cattle from England into this State. Other importations of domestic animals were made by different parties, the stock of 
which still exist to benefit your husbandry. From that time however, soundly slept every thing like State patronage to agriculture, agitated by only an occasional throe at public improvement by the late lamented JESSE BuEL, and a few kindred spirits, whose wakeful minds were ever alive to the importance of agricultural progress; and since the demise of the "Plough Boy," not a single publication devoted to its interest had issued from a public press, until in 1828, when the "New-York Farmer," a monthly periodical, was published in the city of New-York. The circulation of this paper, however, was limited, and its influence consequently feeble in arousing the required interest to resuscitate the effort necessary to awaken the existing torpor of the agricultural community. In 1831 commenced the publication of the "Genesee Farmer," in Rochester, a weekly periodical, conducted with ability and spirit, and now, through its successor, by the same title, continued, in a growing career of usefulness.

But the chief actors in the work which we have detailed, were passing away, and the younger generation taking their places, were gradually catching the spirit of emulation, occasionally thrown off by the survivors, until in February, 1832, a few gentlemen from different sections of the State, assembled in Albany, and formed the NewYork State Agricultural Society, since recognized by the State, and now the body of which you, gentlemen, compose the members. This was seventeen years ago ; and, although in the recollection of most of you, as but yesterday, it is amusing, as well as interesting, to mark the position of the few then assembled-a forlorn hope-in contrast with the attitude you now present in the agricultural interests of this State, and of the American Union. A constitution was formed, a president and four vice presidents elected, and a report of its proceedings published in the Albany newspapers. Among the gentlemen 
then composing that little, yet important body, surviving others who have passed to their final rest, I count now before me a few still active and prominent members from that day to this, honored meantime with its highest confidence, and conferring valuable benefits on their fellow men. Yet torpid, comparatively, as was the action of this body, and obliged to give utterance to its proceedings, save thro' the political papers, which took no interest in its labors, through the then feebly supported agricultural papers at New-York and Rochester, the creation of the State Society rapidly awakened an interest in different sections of the State; and in less than two years from its formation, five or six county societies were organized. In 1833, application was made by the Society to the Legislature, for a law making a public appropriation of money for the promotion of Agriculture, and a report was made thereon in the Assembly by Mr. AvEry SKINNER, of the county of Oswego. But our Legislature were too deeply engaged in the exciting process of creating corporations to listen to the modest petitions, or devote their time to the welfare of the farmer, and the application fell stillborn before them.

Cheered on, however, by the brightening indications abroad, the Society resolved to hold a State cattle show at Albany, in October of that year, and a very creditable display of superior stock, farm products and implements was made; but controlling no funds wherewith to award premiums, it was not successfully repeated during its then existing organization.

In 1834, the Society resolved on the publication of a paper in AIbany, devoted to the Agricultural interest, and the "Cultivator" was established, with Jesse Buel as its conductor. This movement gave at once an impulse to the cause, and awakened public attention to the long dormant subject of agricultural improvement.

Late in 1835, a call numerously signed by gentlemen from different parts of the State, connecterl with the Society, was made through 
the newspapers for an Agricultural Convention, to be held in Albany on the second Monday in February, 1836. Emanating from the State Society, and its prominent members in attendance, a formidable array of numbers appeared on the occasion of its meeting; and to such extent, that in place of the contracted apartments which had hitherto accommodated with entire convenience the Society, while in session, the use of the Assembly chamber was requested for their acaccommodation, and with the usual courtesy of the house, granted for the occasion. Instead, too, of the half concealed sneer on the part of honorable and aspiring members of the Legislature, at first; not only they, comprising by a large majority, other trades and professions than that of agriculture, attended; but that indispensable and time-honored fraternity termed "the lobby," then, as now, an important adjunct to the law making power, with a most disinterested zeal for agricultural improvement, readily joined, as members of the Convention, and became, for the time, most spirited and patriotic farmers; and so far as their speeches and votes in convention were concerned, demonstrated beyond a cavil, the necessity of the fostering aid of the State to the neglected and dormant condition of its agriculture.

But the spirit of curiosity, which attracted many who had enrolled their names as members of that Convention, and who could not imagine what legitimate object there could be in an assemblage of this sort, rapidly changed to a spirit of inquiry ; and during a short session of two days, sufficient matter was developed for a year's reflection on a subject which had now become, to many of them, one of the highest consideration; and it is but an act of simple justice, as well as of true gratification to remark, that many of the present most substantial supporters of the Society, and promoters of its objects, then skeptical to its merits, imbibed their zeal from that Convention, and those which succeeded it. A like convention was held during several successive winters at Albany, and the subject of public aid 
to agriculture each time presented to the Legislature, who continued still regardless of their memorials.

In 1838, then a member of the Assembly, and Chairman of the Committee on Agriculture-a committee so far as practical legislation: was concerned, of no other consequence than to flatter the farmer with the empty compliment that his profession was recognized in State affairs-myself introduced a bill, based upon that of 1819, for the encouragement of agriculture. That measure was well received by the House ; was several times discussed, and I have little doubt, had time permitted, would have received a vote sufficiently large to pass; but owing to the determined opposition of the Chairman of the $\mathrm{Ag}$ ricultural Committee in the Senate, who had imbibed his prejudices from the workings of the law of 1819 , and then declared that he would never report the bill to that body, if it even passed the Assembly, and he too a large and wealthy farmer, the bill was not pressed beyond a few occasional discussions. Sufficient, however, was ascertained of the legislative approbation, to encourage future applications to a successful issue.

The next year, and the next, with accumulated force, and far more formidable pressure, from the increasing multitude of applications; and, urged by the continued annual Conventions upon the Legislature, with many zealous and right hearted members to conduct the measure in both its bodies, our cause indicated a progress that must soon become triumphant; and in 1841, the "act for the encouragement of Agriculture," with an appropriation of $\$ 8,000$ per annum, for five years became a law. In February of the same year, the State Society was re-organized, and its Constitution revised, preparatory to the opening of its career under the provisions of the new act of the Legislature. By direction of its managers, a cattle show and fair was appointed to be held at Syracuse in September of that year, 
which was energetically carried out; and although but an experiment, the result of that exhibition abundantly demonstrated the capacity and disposition of the farmers of New-York to exercise the important trust which had been committed to their hands.

Encouraged by that beneficent law, Agricultural Societies were coustituted in a large majority of the counties of the State during that year, which have since been maintained with increasing zeal and benefit. The law making appropriations for this object has been renewed to the present time; and he must be a hardy legislator who can now raise a voice of potency against its continuance, so deeply grounded are its healthful influences in the affections of our people. An act pregnant with greater good to the prosperity of the State, next to establishing the foundations of social order, and domestic security, never has enanated from your Legislature; and long, long, and with increasing bounty, may it continue!

In viewing the progress of this great measure through its first feeble efforts at existence, until its final consummation by law, and its rapid advancement since, an acknowledgment of deep gratitude is due to the liberality which has pervaded the ranks of those professions and occupations in our community not agricultural. The most formidable obstacles which the promoters of this institution have met in all their efforts, were either the determined inaction, or direct opposition of the mass of the farmers themselves. I speak this more in sorrow than in anger, that they who were to be most benefitted by its results, should be the slowest in yielding it their support; while those of the learned professions, the mechanics, artizans, and merchants generally, both in and out of the Legislature, and throughout the State, gave to our efforts a general and hearty concurrence. The comparatively few practical farmers whose zeal and co-operation would take no denial until success had crowned their efforts, represented, with but 
few exceptions, an inactive and thankless constituency at home. It is, however, most consolatory to remark, that the practical operations of this and the county societies have awakened a spirit of emulation and enquiry among the mass of our farmers which, although slow in its growth, must ultimately be crowned with the most gratifying results.

Nor is the inactivity complained of, perhaps, unnatural on the part of the agricultural class. Engaged in a retired and domestic occupation; unusued to habits of professional association, of which they have not been taught the necessity, nor felt the stimulating influence, they have neglected to adopt that combined action which distinguish the other professions, and is the main spring to their success in the improvement which they so rapidly accomplish. But we are ascertaining that this system of association, in order to advance to any high degree of improvement also, we must effectually practice; for it is only to the habits of inquiry, and examination of whatever subject he may have in hand, that gives success to the master of any occupatlon whatever. Why is it the fact-and fact it is-that many of the best and most successful farmers in our country are those, who, bred to other pursuits, and toiled in them to middle age-and many far beyond it-tlll from inclination, or necessity, they have embraced agriculture as an occupation, with a determination to succeed ? It is because investigation has been the habit of their lives. They do nothing without a good and satisfactory reason for doing it. They bend every faculty of the mind to acquire success in this, as they did in their previous pursuits; and the application of the same intelligenee upon the farm that had there been exerted, produced the same results, although their early education and subsequent labors had kept them in profound ignorance of the simplest rules of practical agriculture. The most gratifying success has been thus accomplished, while he, who has from childhood tilled his paternal acres in obstinate and per- 
severing ignorance of the true principles of his art, although scorning in the pride of his own fancied superiority, the more timid efforts of his thoughtful neighbor, delves on through life, a wre tched and unsuccessful farmer, and in time leaves the world no better, so far as his own labors were concerned, than he found it ; and is finally buried beneath a soil over which he plodded for three score years, and never knew a single part of its composition !

This, though perhaps an extreme, and certainly not a flattering picture, is still a type of agricultural life, in its way, existing in every one of our United States. In what profession throughout the length and breadth of our land is there so little progress-nay, such determined opposition to progress, as in the ranks of agriculture ? I would not assert that numerous eminent examples of improvement have not existed among those of purely agricultural occupation. But they are rare as compared with men of other pursuits when applied with all their research and intelligence to agriculture alone.

And it may well be inquired, why is this so ? Agriculture occupies four-fifths of the laboring population of the land. From the agricultural ranks have sprung many of the most illustrious names whose services hare adorned and honored their country. From its ranks, too, have perhaps a majority of the most successful among those engaged in the various other pursuits and occupations of life arisen. In short, there can be no class of our population which affords so sure a basis on which to rely for an infusion into all other pursuits to the durable prosperity of a State as the agricultural. Such is the gratifying truth; and it is to the health-giving influences of the soil itself; the free wild air of heaven that he breathes; cheerful exercise and occupation; contentment; and the full, unrestrained enjoyment of man's first estate bestowed by God himself, that thus constitutes in him who tills the soil, the full development of his faculties in all the admirable proportions of body and of mind that his 
Creator intended. Notwithstanding all this, the question still recurs, and may be variously answered. The very ease and contentment of condition in the farmer, is one probable cause of his inactivity in improvement. The quietude of his avocations prevents that constant attrition of mind inseparable from the bustling activity of most other pursuits; and the certainty with which the soil yields its annual tribute to his labor, dispels that spirit of investigation common to classes the result of whose labors is contingent or uncertain. Nor yet is the farmer an ignorant, or a slothful man. In the great responsibilities of life-in domestic duty-in love of country-in the orderly support of the institutions of the land-in stern watchfulness over the acts of those he has placed in authority, and in that exalted patriotism which is ever ready for the heaviest sacrifice to the benefit of his race, he, as a class stands without a rival. And yet, possessed of all these qualities, and enjoying all these advantages, the absence of the spirit of association, leaves him in effect the least benefitted at the hands of those he elects to govern him, of all others.

Who invents, improves, and perfects the plow, and all the nameless implements which alleviate his toil and accelerate his labor? Who analyzes his soils, instructs him in their various qualities, and teaches him how to mix and manure them for the most profitable cultivation? The mechanic-the chemist. Who, ascertaining that his seeds are imperfect and unprofitable, searches foreign lands for new or better ones, and introduces them to his notice? The commercial adventurer, or the travelled man of enquiry and observation. Who, on comparing the inferior domestic animals which he propagates, and in whose growth and fattening he loses half his toil and the food they consume, sends abroad, regardless of expense, and introduces the best breeds of horses, cattle, sheep and swine for his benefit? In nine cases out of ten these labors and benefactions-and their name 
is legion-are performed by those whose occupations have been chiefly in other channels, and whose agricultural tastes have led them into the spirit of improving it. And in how many examples have we witnessed the apathy, if not determined opposition with which the farmer proper-or at least he who claimed to be one-has set his face like flint against their adoption, even after their superiority had been demonstrated beyond a question!

So, too, with the farmer's education. They have been content that the resources and the bounty of the State should be lavished upon the higher seats of learning, where the more aspiring of our youth should receive their benefits, not caring even to inquire whether such youth should again return among them to reflect back the knowledge thus acquired. They have failed to demand from the common treasure of the State those necessary institutions which shall promote their own particular calling, and which every other pursuit and profession in the land has been most active to accomplish. In all this the latter have progressed with railway speed; while the farming interest has stood still with folded arms, and done comparatively nothing; and what good has been forced upon it by others, even regarded with suspicion. It is not because we as farmers, compared with others, are either ignorant or stupid. We only neglect to assert our rights, and appropriate the share to which we are entitled in the common patronage of the State to the benefit of our own professions. It is for us to ask-to will-to do it. We hold the power of the State by our numbers. We can control the halls of legislation. We can so direct the laws that we may share equal advantages in our institutions with others. We desire nothing exclusively to our own advantage, but we do deserve an equal participation in those institutions established for the common benefit of all. 
If a practical inference may be drawn from the thoughts thus desultorily thrown together, it would be that, from a history of the past, and the condition of our agriculture as it now exists, we demand that our profession shall be placed within the reach of equal advantages for improvement that are now enjoyed by other professions. Under a condition of things constituted like those which we have discussed, you, gentlemen of the Society, have labored during the last seventeen years, through anxiety and toil, directed by honest purpose and intelligent action, until you have arrived at a successful issue. It has been a labor if not of discovering the precious metal in the earth at least that of removing the inert mass from the surface, to the quarrying of the mine, and the upraising of the valuable ore to the admiration of the community, to be wrought by skillful artizans into handiwork of infinite utility and ornament. Aside from metaphor; a mass of long slumbering prejudice and inertia has been removed; the spirit of improvement has been awakened; our agricultural resources have been partially developed; our exertions have won an acknowledgement of the importance and dignity of our calling, which none can gainsay; and it is thus that your Society, through its labors and results, now stands an object of respect and admiration to our countrymen. A great good has therefore been effected, and in contemplating the position which your Society now occupies, I do it in no exulting spirit of laudation, or of triumph, but as admonishing you, that having accomplished so much, you have the highest incentive to still further, if not weightier labors and achievements. Not content with creating an institution which holds an established rank among kindred institutions abroad, and maintaining honorable and kindly intercourse with them; nor that you annually draw out the farmers, mechanics and citizens of this and of neighboring States 
in laudable competition for superiority in their productions, and ingenuity, and giving the results of your investigations to the worldhigher objects await your efforts, and invite your attainment. You will bear with me, I trust, while I offer such suggestions on this interesting topic as shall appear germain to the occasion.

Agricultural education should attract largely your attention; and it is a subject which will bear a little examination. The pittance of $\$ 8,000$ a year is now doled out of your public treasury, a bare recognition only of the importance and value of agricultural associations, of which the stipend of $\$ 700$ is paid to your Society. To call this State bounty, which we in courtesy do, is little better than mockery. Forty thousand dollars a year would now be less, compared with the wealth and resources of the State, than $\$ 10,000$ in 1819 . Why, gentlemen, the annual appropriations to agricultural advancement from the State Treasury, is less than that given to three of your colleges, where less than two hundred students yearly graduate. Appropriations amounting to more than $\$ 500,000$ of public money have been made by law for the endowment of colleges; and your Literature Fund is still annually drawn upon to the amount of $\$ 15,000$ in contributing to their support, while their halls remain a sealed book to him who looks only to agriculture as the profession of his life ; and of the thousands who there receive the bounty of the State in aid of their education, not a tithe of them in the course of their lives add a dollar to the physical or productive wealth of the country. The common school, or the village academy is the only institution where the young farmer gains admittanee; and even there, as at present constituted, he hardly acquires an idea of the rudest elements of his future profession, or of those studies which properly belong to it.

These remarks are not made in a querulous or fault-finding temper. It is right that we have colleges, and academies for the few who as- 
pire to the higher walks of professional or scientific life, as well as common schools for the million. No State can be well, or wisely constituted without them, and I would not abate one jot or tittle from the wholesome support which a broad and liberal system of education demands. But we should claim, and insist, that departments devoted to agricultural teaching, or to the development of agricultural science, should be established, either as branches of our seats of learning, or as independent institutions. Why should not the farmer be educated to the top of his faculties, as well as those who select what are termed the learned professions as their pursuit? If our sons cannot be taught the education they seek in the colleges-and there are well grounded doubts of this fact from the moral malaria too often existing within and around them-institutions for their sole education should be aided, or erected, and endowed by the State. This subject has been annually debated in your meetings for years past; but influenced by a strange timidity, no decided action beyond a formal and altogether harmless expression of opinion has been effected. I beseech you, gentlemen, to look at this matter. The real and personal property of this State is more than one thousand millions of dollars. Nominally, in the assessors returns, it is rated at less than 650 millions. In these returns, it is notorious that real estate is not assessed at over two-thirds its real value, and it is safe to say, that owing to the imperfect and partial system of taxation, not one-half the personal property of the State, comparatively little of which is held by the farmer, is taxed at all ; and in its practical operation, agricultural capital pays two to one over that devoted to other purposes. Yet with all this burthen on its back, the farming interest either stands back from your halls of legislation abashed, although nominally represented there by its members; or if plucking a momentary courage by the congregation of its numbers on an occasion like the present, it literally shrinks away, either ashamed to ask its rights, or 
if asking, couched in such a subdued tone of humility, that the Legislature scarce believe you in earnest. This, gentlemen, is your attitude before the temporary power which you create to govern you! Contrast it with the conduct of those who seek a different kind of favor at its hands. Watch the thousands of applicants for corporate, and exclusive privileges, and State patronage, who have in times past beseiged your halls of legislation. With what confidence they approach and lay seige to the law-making power; and how like "sturdy beggars" they persevere, till, wright or wrong, their importunities are granted. And in parenthasis I might continue to remark, that the history of our corporate legislation is monstrous. Some years by gone, and banking charters were the only subject of moment before these bodies; and that legislator who did not go home with more or less of the promised shares of a successful application in his pocket, was considered as but a dull financier, or strongly suspected of having what, in private life, is called-a conscience! In later time, it has been asserted that railroad corporations have controlled your Legislatures-ridden into their seats by aid of free tickets; and cotemporary with them, had we farmers caught the spirit of the day, and adopted characteristic weapons of success, each one of us would have appeared with a sheep on his back, or a truss of poultry at his elbow, to lunch them into acquiescence!

But, badinage apart; this is a subject of serious, of momentous consequence, not only to us, but to the State at large. We are a growing people; not in population alone, but in wealth, and in resources. Our whole country is comparatively new, and wealth is accumulated with us as with no other people of which history gives an example. I speak of substantial, enduring wealth; that which adds to the enjoyment, the happiness, and the truly elevated condition of man. Of all this wealth and prosperity, agriculture is the basis-the indispensable support. Yet, 
in defiance of this reiterated truth, as an occupation, agriculture of itself, is degraded. Let politicians, or demagogues chant their paens to the tillers of the soil as they may, and tell them of the honor, and the dignity of their estate; yet, practically, simple farming is considered by those who assume to give tone and opinion in social and political life, an inferior occupation, fit only for dull, unthinking, and uneducated men. Were it not so, why are the Agricultural ranks so continually deserted by our active and aspiring youth for the more worldly popular pursuits, under the belief that they are more advantageous? Look at our great, bustling cities, and towns. See on all sides our professions crowded to excess; with, among the masses which throng them, but a comparatively few who are successful either in fame or fortune. View our merchants, and shopkeepers, overrun and undermined in competition with one another; and clerks, and shopboys plentier and cheaper on their hands than the wares they hold on sale; and all the motley congregations which are drawn about them by the spirit of adventure and of novelty; while the petty political offices of the day are held up like lottery tickets, to an unscrupulous and indiscriminate scramble;-all for the possession of a fancied prize in the great raffling match of adventure ; while the shop of the mechanic, or the artizan, which holds out a safe and durable reward to honorable labor, is hard pressed to find apprentices; and the broad, inviting acres of the farmer, are lying sterile or unproductive, for lack of cultivation.

In ministering to this vitiated appetite of discontent, the farmer himself is oft times blameable. In a too humble estimate of his own condition and character, and in the absence of those advantages for his children, of which he himself has felt the want; with a fond desire for their welfare, he has encouraged their early restless propensities; and hoping that the wide world of chance, or speculation, or luck, would cast them in a happier lot than his own, has pinched the al- 
ready limited share of himself, and those who yet prefer the quiet homestead, to fit out for some undecided profession, or dubious branch of traffic, him who, under this misplaced partiality, now goes abroad, in time to return, a prodigal son, or, as is often the case, to beggar the family by his extravagance.

On the other side, it may be said, that the enterprising lad, thus leaving his home with laborious habits and well fixed principles, soon engages in some active pursuit, and succeeds far beyond a brother of perhaps equal talent, who has remained at home, and only inherited the toil and poverty of the parent, in whose track he had diligently pursued. Very true; but mark the difference in advantage. The adventurous youth had fallen on a beaten track, with intelligent lights to aid his course, which, only to follow with engergy and prudence, was to succeed. The other had groped along in a cloud of traditionary fog, and floundered on in the uncertainty of guess-work, with no accurate light to guide him; like the mariner who departs on his voyage, with ship and sails to be sure, but miserably appointed, without rudder, chart or compass; while the first, with ship well found, and a master mind at helm, is wafted on to a successful destination.

Do you ask for the reflux of tide from the mass of other to Agricultural pursuits? You look for it in vain. How many, bred in our cities, towns, and villages, seek the farm for employment-leave the too often casual occupations of the crowd, and take to the plough, or to the forest? None whatever. Or if, perchance, there be an isolated case of the sort, it is, when following the parent, who, tired of the world's vanities, or its fitful changes, wisely retires to the farm for that solid good which a bustling world had denied him.

There is another great and responsible class among us who have an abiding interest in the exaltation of our Agriculture. I speak of the wealthy classes distributed throughout our cities, towns, and villages. Owing to the free and happy institutions we enjoy, well directed in- 
dustry, coupled with perseverance and economy in most branches of business, is tolerably sure to succeed. But with the success of the parent, and his consequent devotion to the labors of his office, or his counting room, that necessary vigilance and watchfulness over the proper education and employment of his child, is too often neglected. Honestly feeling the strength of his own self-reliance, he trusts that the son may follow in his own laborious and successful course. But a few years only pass, and that son has arrived at manhood, vitiated, perhaps, by adverse associations, or if still within the path of safety, unfitted by education, or the false estimate of his position in life, to succeed in the beaten track of parental example. In a great majo. rity of cases, capital, toilfully gathered, and safely invested, is squandered, or lost in business adventure by the misapplication of the son, while the hopeful parent had never considered, that when he had furnished the means, he could not regulate the brains to control it; and after, perhaps, repeated trials, he withdraws him from business altogether, an unsuccessful and disappointed man; and the parent himself, if he escape the ruin of the son, is at a loss to know how he shall provide for his decent employment, or witness the wasting of his own gains during life time in an unprofitable support-for in this country, thank God, a man must do something to make him respectable. And yet the well meaning and laborious parent is scarely to blame. He has looked abroad among the pursuits of the world, and finds none more generally successful than the one he himself has occupied. But risen, perchance, from comparative poverty himself, he cannot realize that the strong incentive for exertion, which existed in his own case, is absent in the son, and therefore, that they each look out upon the world from widely different premises.

Nor, during all this probation of anxiety and solicitude, has it ever occurred to the father, that Agriculture held out the safest mode of investment for a portion of his gains; and if not the most rapid in 
accumulation of worldly goods, was, at least, the surest pursuit for his chilliren, in the absence of that successful tact which he himself possessed for professional, mercantile, or mechanical life. But he has, on the other hand, imbibed the popular and mistaken notions of the day on that subject. He might, like others who fancied they had some $\Lambda$ gricultural taste, have had his own country house and farm, got up at great expense; and been pestered with worthless servants, and dishonest managers, who only pillaged and worried him ; and after a brief and unsatisfactory trial, abandoned it in disgust, like hundreds of his friends and neighbors; never dreaming that his farming got on quite as well as his law, or his trade would have done, with the same amount of his own personal attention! That, and the drudgery of the ordinary farmer, who tilled his own scanty acres in his immediate neighborhood, and whose association, as ignorant and degrading, he had scorned, were the only experience he had known, on which to make up his opinions; and as a matter of course, he only knew agriculture to condemn it.

But had Agriculture her proper institutions, where his children could have been taught its necessary education and practice, and exerted its proper influence among the pursuits of the day, how readily would he have embraced the advantages it offered to his family, and eagerly bestowed the best talents of his sons to its rewards! Thus prepared to enjoy it, how many thousands of men, rich in the acquirement of proper knowledge, and fortified in the possession of wholesome estates, would be shining examples of thrift and improvement in our midst! Ample domains, with broad cultivated fieldsspreading pastures, dotted with the lively spectacle of flocks and herds-meadows, waving under the burthen of their luxuriant grasses; and graced with comfortable mansions and bending orchards; and peopled throughout the year with those who really felt the dignity of their calling, would spread along your noble rivers; and look abroad 
from your lofty hills; and line in beautiful relief your canals and thoroughfares-spectacles of home bred comfort, and independence, illustrative of true American character. But instead of these, are seen the fantastic villas, and ephemeral erections, which perk up in ambitious pretension on the elevated knolls of your noble Hudson, the summer abodes of "fancy farming," only to be abandoned after a few brief occupations in a round of ennui killing pastimes, and voted -a bore. Such empty essay at Agricultural life usually ends in the squander of what would, if judiciously invested in a useful farm, have been a handsome estate, and is sold, perhaps, under the hammer, at a tithe of its cost to some man of better sense, who pulls down the bauble, or changes it into an appearance of propriety, and appropriates the soil to useful purposes

It may be said that these pictures are of extreme cases. So they are. And also that they are subject to many proper exceptions. Very true. But they do exist, and that in far too great numbers, and scarce one of us but knows an instance of their just application. Still there is a great class left: the substantial middle class of our farmers, who require for their sons, destined to follow in their own steady course, that necessary kind of education at present unattainable in our country, and which can only be properly given in agricultural schools. The young farmer painfully feels the want of advantages which these would confer, and the aid of which, he vainly seeks elsewhere; and the question, how are we to accomplish the object, remains to be answered.

Although keenly alive to the necessity, I, for one, am not prepared to submit to you a definite plan; yet am prepared for prompt, vigorous, and decisive action. In the first place, I believe a trial of some kind-an experiment, if you please-should be made. Our State has not been fearful to make experiments in the establishment of any work, 
the practical utility of which has once been settled. A few thousands, nay, millions of dollars, have not deterred our legislators from either taxing the people, or appropriating its already accumulated treasures for works tending to the public welfure. Our literature and common school funds liave been augmented in various ways, until common education throughout the State is almost free, and in some communities absolutely so, by the aid of general taxation on property. Medical institutions, as well as colleges, have been largely endowed, and are still assisted by the State; and you have abundant example that the disposition has not been wanting in our government to execute, where the great constiutent body has demanded the work. The propriety of this measure has reached your high places, and I refer with great pleasure to the recent message of Governor Fish, who, in view of the benign results accomplished by your society, has emphatically recommended "the endowment by the State of an Agricultural School and a school for instruction in the Mechanic Arts;" and this, if followed up with the zeal and earnestness which its importance demands, you may certainly effect. I cannot believe that a wise and intelligent Lcgislature will longer deny your prayer. It may be said, that we have in this country no examples from which to copy an institution of this kind. No matter. They exist abroad, in the full tide of success, far beyond the probation of experiment; the Hofwyl School, in Switzerland, founded by Fellenburgh, for example, to say nothing of others, equally successful, in other countries of Europe. 'To them might Commissioners repair, at a moderate expense, for models of instruction, so far as they are adlapted to our wants and condition; and were it not so, it is but a poor commentary upon American ingenuity and enterprize, to halt at any thing supposed to be ultimately attainable, without the strongest effort to effect it; and we can no more doubt the final success of institutions of this kind, than we can doubt the conquering career of the steam engine, or the electric battery. 
The laying deep and broad, the foundations of a State Agricultural School, subject to an equal ratio of scholars from the sereral counties of the State, would be in accordance with the already established plans of distributing the public benefits of education, and liable to no objection. Thus, the necessary knowledge, so acquired, would be carried back among our population, to be spread broarlcast, in the remotest districts of the State, through branches of other institutions, which might be set apart for that purpose, or established independently, through private liberality or enterprize. It cannot be expected, indeed it never was anticipated, that the State Agricultural Society should embark in a work of this kind; it has neither the necessary funds nor the corporate strength to effect it, and in pursuing the correct path already indicated, it has abundant exercise for all its functions. Yet its advisory aid and co-operation would be invaluable, and greatly add to the utility and success of any agricultural institution.

Aside from the establishment of an independent School for agriculture, the State inight with great propriety provide a department in the Normal School, now becoming a settled branch of public education, for instruction in the principles of Agricultural Science, which, from them, might be taught in the common schools. Popular works on Geology, Agricultural Chemistry, Botany, Animal, and Vegetable Physiology, the plain principles of Mechanic Art-all which are indispensable to the proper education of the farmer, might be taught in a plain, and simple course of lessons, as easily as the ordinary rules of arithmetic, or mathematics; and a knowledge of these would be the source of satisfaction, if not of future profit, to every scholar. "During the past year," I quote the language of Governor Fish, " $\$ 81,624.05$ have been expended by the State for the increase of books in the school district libraries, to which have been added, one million three hundred thousand volumes." Works of the kind which have been 
mentioned, together with well approved Agricultural books, should form a portion of the annual additions to these libraries; and if such works cannot be found, the necessary authority should be created for their compilation. Thus you provide the means of self instruction in a great degree, to the humblest and most obscure inquirer, and that without cost.

In these last suggestions, I am gratified to remark, that we have the testimony of such high authority as the late Governor Wright, in the address he had prepared, and which was read after his lamented death, before your Society, at Saratoga. It was a subject to which he had, unquestionably, given much of his strong and vigorous thought, and may be well received by us as worthy of profound consideration.

Let us then commence the work, and proceed until we effect this momentous object. Let it become the duty of a committee of your body, to take the subject in charge, and wait upon the Legislature, with all the resources they may command, to aid them in enacting a law, and to carry out its provisions. This once effected, your future success is certain. The time is auspicious. I believe the public mind is prepared to receive it, and that it will be hailed with heartfelt gratification by all classes of our community.

Among the benefits arising from well directed Agricultural education, aside from spreading the requisite learning and intelligence applicable to the chief pursuit of our people, deep and broad among them, the retention of that portion of active capital, acquired by the industry of our Agricultural population, among themselves, would be one important consequence. In place of the prevailing and mistaken notion that monied capital invested in agriculture is either unproductive, or less so than in other pursuits, our farmers would be taught that, coupled with ihe knowledge to direct it, no branch of our national 
industry is so steadily remunerating as that connected with the soila fact now practically disbelieved; or why would such amounts of monied capital be continually drawn from the agricultural districts to your commercial cities, to be embarked in hazardous enterprises, or doubtful investments? The merchant, or the speculator may fail-and fail he does, very often-and in his downfall is often buried the toils of a long life of patient industry. But who ever knew a good farmer, of prudent habits to fail? Nay, who did not, with an exemption from extraordinary ills in life, ultimately grow rich, and discharge meantime, all the duties of a good citizen? I concede to you the many prominent cases which exist, of wealth rapidly accumulated by bold and successful speculation; of fortunate, perhaps accidental adventure; of hoards heaped up by a long course of perseverance in trade, directed by that intuitive sagacity of which but few among us all are endowed, and which so dazzlingly invite our imitation. Yet these are but a few glaring instances, standing out in bold relief among the many who have sunk in the same career, perhaps with a ruined peace; happy afterwards to retire, were it in their power, upon the limited possession which they had thrown away, to commence their wasting strife upon the broad sea of adventure.

A second advantage would be, that it would invite, annually, a large class of educated men of capital from our cities, to invest a portion of their wealth in our farms, convinced by the knowledge acquired in a course of agricultural education, that Husbandry was a good business, and intending to pursue it as the occupation of their lives, it would cause a reflux of that capital and population which had been drawn away from agriculture. Nor would such associations among us detract from the industrious habits of our farmers by their example. They, by the possession of larger estates than we enjoy, might give more of their time to leisure than we are accustomed to spend; but 
they must, if good farmers, attend to the daily routine of their affairs, as well as we. They would diffuse intelligence among us; introduce improved implements, seeds, and stock; and in time, surely exalt the character of our husbandry. They might not, indeed, work at the muck heap, nor guide the plow with their own hands; but they must be capable, from education, to direct the labor of both; for we must not forget that the merchant who, from his luxurious counting room, plans his voyages, and directs the course of his ships; or the engineer who projects the rail-way, or the ocean steamer, once performcd the duties of a shop boy, or hammered at the anvil. And thus with the farmer: he should be capable of directing the cultivation of the soil to its greatest possible extent of production; and he will find that, in achieving such result, all the powers of his mind, and the knowledge with which it is stored, will be required.

This thought will bear a little examination. The farmer is apt to think that the professional man, or the merchant, lives an easy and luxurious life. In many instances their families may do so; but with the eminent and successful man of law, or science-the artizan, or merchant himself, such supposition is a great mistake. There are not, under heaven, a more laborious class of men than these. Labor of body, and of mind is theirs-and that incessant. See them early, late; in season, and out of season-their whole energies devoted to their several callings, without rest, or intermission-and far too fiequently, to the premature wasting of life itself. It is no wonder that such industry, directed by good education, (and by this term I mean the entire training of the boy to manhood in its most extended sense,) and stimulated by a laudable ambition, should lead to success. Yet with all these appliances, the labors of such men are often disastrous; and if not so, after a life of anxiety, their toils too frequnntly end with but the means of a slender support. Compared with these, 
the toils of the farmer are light. Physical labor he endures, it is true, and often times severe labor, but his mind is easy. He enjoys sound rest, and high health. He has much leisure; in many cases more than is for his good. He has abundant time to discuss politics, law, religion-everything, in fact, but what relates to his own profession, on which subject, I lament to say, his mind seems less exercised than on almost any other. Now, let the same early education be given to the young farmer of an equally acute intellect that is given to him who chooses professional, mechanical, or mercantile pursuitseducation each in his own line. Let them start fair. Apply the same thought, investigation, energy, and toil, each in his particular sphere, and beyond all question agriculture will, in the aggregate, hare the advantage-and for this reason, if no other: there are few contingencies connected with agriculture. Its basis is the solid earth, stamped with the Divine promise, that while it remains, seed-time and harvest shall continue; while commerce, and trade; mechanics, and arts are liable to extraordinary and continual accident. Look at the devastations by flood, and fire-of ship, and cargo, upon ocean, lake, and sea, and river; conflagrations in your towns and cities; and the thousand other casualties which almost daily occur-all which are a dead sink upon labor and capital not agricultural, and the risks of the husbandman are scarce one to ten, in the comparison. Rely upon it, Farmers, you are on the safe side.

But, I hear some one remark, "Why, if agriculture, through the improved education proposed, holds out such alluring advantages, all our young men will rush into it, and competition will destroy it." Not the slightest danger. Our young men are already running into the other trades and professions, where competition is ruinous; and all we ask, is the opportunity to get a share of them back again. Besides, there is no fear that the other avenues of industry will not 
be filled; for, in the constitution of our natures, there will always be enough unquiet spirits born into the world which the farm cannot hold, to keep the bustling part of it in motion.

Another, and a prominent advantage which we should receive from good agricultural education, would be, that of more stability of character in our farming population. It is proverbial among traveled foreigners in this country, and it would be a subject of wonder among our staid people at home-if an American could wonder at anything - that we are the most changing people in the world. We, as a population, have few, scarce any, local attachments. This, to an extent, is a true, although a severe censure. It arises, no doubt-and naturally enough, too-from the wide extent of national domain of which we are the possessors, and from the natural sterility of much of the soil in our older communities, which cause an effort, and a laudable one, too, to better thes condition in our rural population. But more, I imagine, from the low standard of agricultural improvement, and a mistaken estimate of the value of the soil, and its application to the products which properly belong to it. But, no matter what the cause. The fact is so, and it is a defect in our national character. How many among us but will, with a slightly tempting offer, sell his humestead without remorse-break up the cherished associations of his life-turn his back upon the graves of his kindred, and his children-his birth-spot-the old hearth-stone of his boyhood -his family altar, even the brave old trees, which have, life-long, waved their branches over his childish sports, and shadowed his innocent slumbers when weary of his play, all-all, pass out of his hands, like a plaything of yesterday, unwept and unregretted, for the fancied advantage of a fresh spot in a strange and a newer land.

I must, however, in justice, make some exceptions to this general propensity in American character. There are some among the descend- 
ants of the early New England Puritans, and the ancient Dutch settlers of this State, who have, with a pious regard to the memories of their ancestors, and a wise attachment to the spots of their birth, retained, and, through the influences of a correct education, and well settled principle, bid fair to retain, the paternal acres which they have inherited-homes of plenty, contentment, and genuine hospitality; where retired virtues, like those practised by their fathers, have long hallowed them with a local habitation and a name. Such, stand out as strong landmarks in the fitful changes of place, and name throughout our country, and redeem, to some extent, the caustic remark of the late John Randolph, of Roanoke, who once declared, on the floor of Congress, that he scarce knew an American but would sell his very dog for money!

We are not slow in finding out when we are well off, although all are nat satisfied under such condition; but with these advantages around and among us, of which we feel the daily benefit, and of which, by removal, we should forever be deprived, their tendency would be to fix us more firmly to our homes, and lead us to examine the resources within our reach, which otherwise might never have been developed. Associations of an elevated character are among the most powerful in thus keeping us content; and institutions in which the farmer has a direct interest, would, more than almost any other, allay this tendency to change. Our resources, and our productive power, are thus retained, far beyond what can be acquired by the continued restlessness common to us. Such influences wonld certainly be most wholesome.

Another, and the last valuable aid derived from a dissemination of Agricultural Science, which I shall mention, would be the establishment of correct standards of judgment to govern awards at your sarious cattle-shows. We now congregate together from all parts of the State, and invite our brethren from other States to exhibit their 
productions by the side of our own. But by what rules are those productions thus brought into competition examined, and your prizes awarded? Why, from the very necessity of the case, no rules at all. Your examining committees, having no standard by which to judge the comparative scale of excellence in domestic animals, excepting, perhaps, a false estimate-or prejudice-or individual taste, differ widely in their opinion of what is good, or what is bad; of what is deserving, and what is undeserving; and with all the flourish and eclat of a splendid and imposing show, perhaps the worst animals take your highest prizes. As a consequence, the truly good and scientific breeder leaves in disgust; while the careless, indifferent one, walks off in triumph, glorying in the brute which ignorance, accident, or chance has thus given him credit for, and he is forever ruined for all further improvement, by having his ignorance or prejudices endorsed by the Society, and holds, as a matter of course, the useful and accurate breeder in contempt. All this mischief, Agricultural Education and Science would rectify; and that not alone. The adoption of rules of proceeding based upon accurately defined results, and ascertained through correct principles, would give to your Society that high stamp of authority in its decisions which, from its name and position, it should command; and without which, it must remain shorn of half its utility.

I have thus, gentlemen of the Society, tediously to you, I fear, thrown together the imperfect and random thoughts which this subject has suggested;-a subject which lies near my heart, and has long been to many of you one of deep solicitude. If, in the arguments and illustrations advanced, I have spoken some unwelcome truths in a tone of apparent censure, and kept back the voice of commendation, it is not that I am insensible that we may also contemplate the many subjects of gratulation and pride, which exist around us, and have been won by the labors of an intelligent, an active, and a won- 
derfully energetic people. Inhabiting a State urivalled in its fortunate position among the constellation with which we are numberedpossessing the great entrepôt of our national commerce-and through our magnificent works of internal improvement, become the carriers for almost half an empire, disbursing, annually, millions of revenue derived from our public works, through our State Treasury-cultivating a soil eminently kind in its agricultural productions-enjoying, almost without a parallel, the benefits of civil, religious, and literary nstitutions, steadily shedding their lights and their influences over a well ordered and rapidly improving people ; it is with a heart of exaltation that I feel our course to be onward, to the consummation of a more perfect day. We shall attain the great and beneficent objects we demand; and if we do not now succeed, I have an abiding confidence that our fervent wishes will yet be accomplished-a crowning work among the munificent institutions which grace, and dignify, and elevate your State.

In contemplating the progress thus far, of your Society, and the results of your labors, you have just cause of satisfaction. You found the ore in its dross; you have ascertained the method of its separation, and defined the process of working it successfully into those useful and enduring forms which not only benefit the State, but redound to your own good name. You have only to persevere, and higher-more perfect attainments await your exertions.

In now taking a final official leave of you-resigning, I trust, to more efficient hands, the honorable post to which, a year ago, your kind partiality assigned me, I can only regret that I have not possessed more ability to aid your exertions, and a more extended influence to draw into your support. My honest efforts, such as they were, have been devoted to your service. May Heaven's choicest favors rest upon your labors for the welfare of your fellow-men. 
Permit me now, gentlemen, as my last presiding act, to introduce to you the President elect of your Society, the Hon. John A. King, of the county of Queens-in whose long association with you, and the hearty zeal he has invariably manifested in the labors of this Society, we have every confidence that his best efforts, and most diligent labors will be exerted in your cause. 


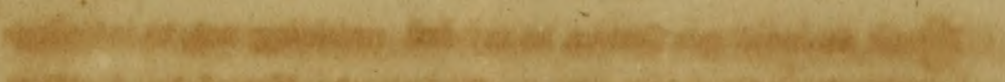

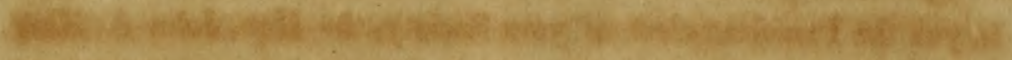

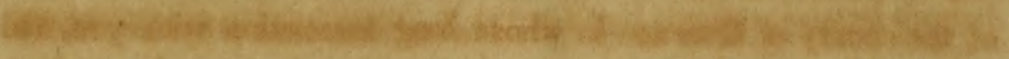

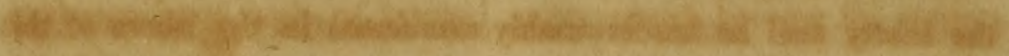

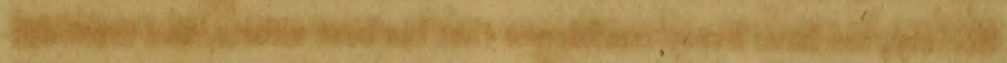

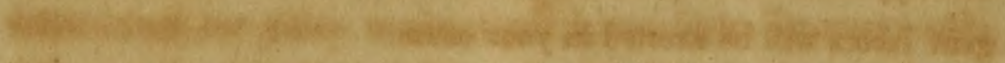

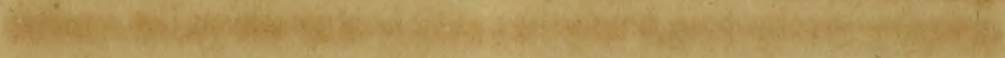

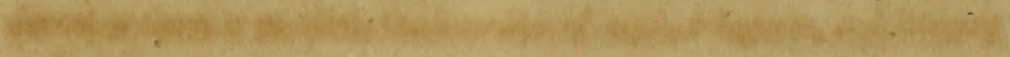

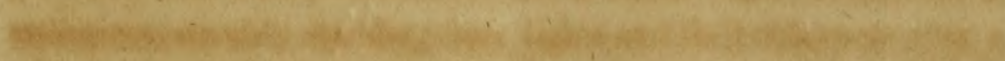

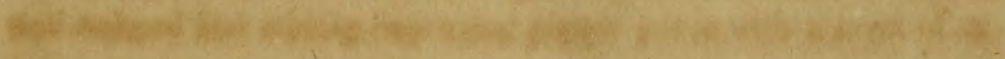

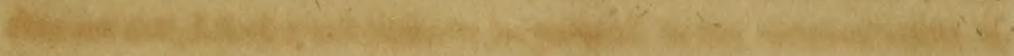

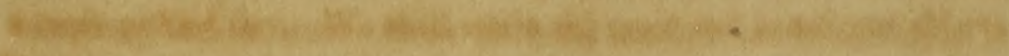

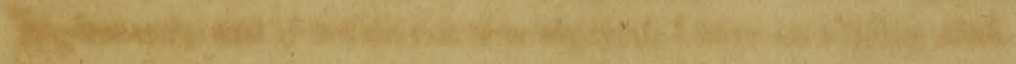

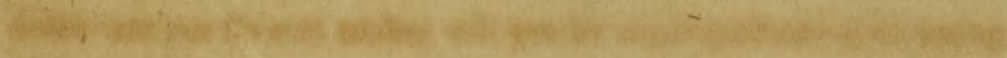

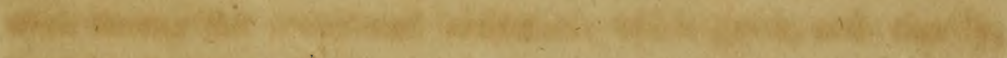

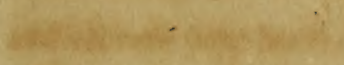

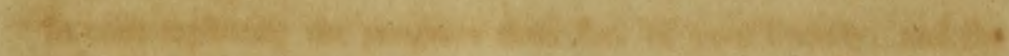

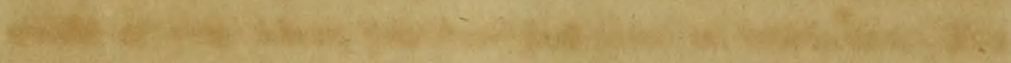

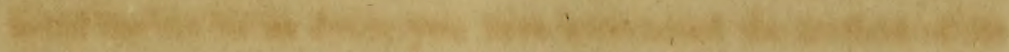

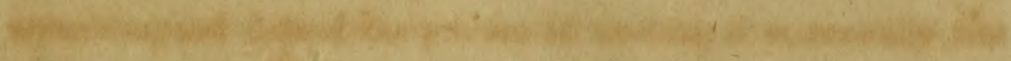

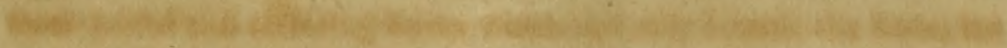

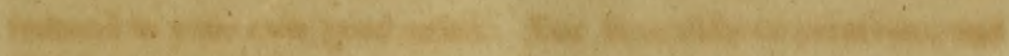

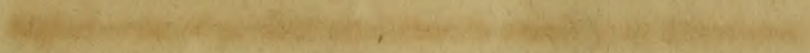

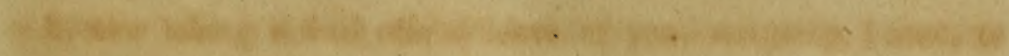

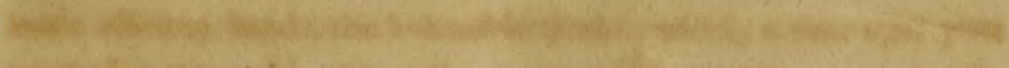

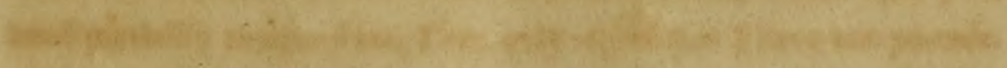

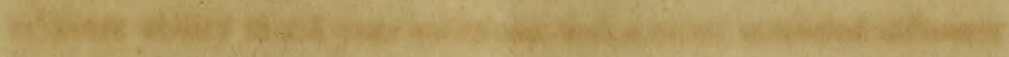

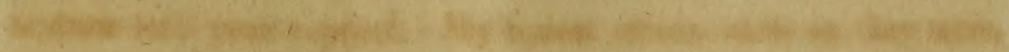

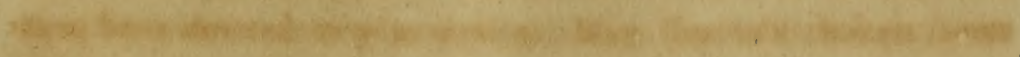

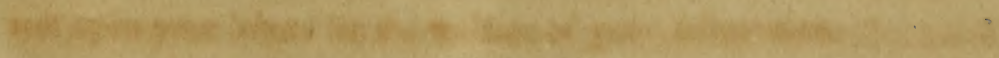

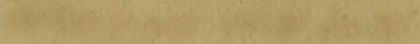




\section{LIBRARY OF CONGRESS}

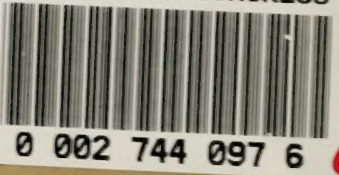

00027440976 